\title{
Gender in Ann Veronica: A Critical Discourse Analysis
}

\author{
Zhino Jawhar Abubakr ${ }^{1}$ Lubna Fadhil Ahmed ${ }^{2}$ \\ ${ }^{1}$ Department of English Language, Faculty of Humanities and Social Sciences, Koya University, Kurdistan Region, Iraq \\ ${ }^{2}$ Department of English Language, Faculty of Humanities and Social Sciences, Koya University, Kurdistan Region, Iraq
}

\begin{abstract}
This study investigates the differences that can be detected in the language produced by male and female talk. The study's specific focus is on gender performance by both interlocutors. It concentrates on the way gender is represented in the $20^{\text {th }}$ century British novel by considering social, cultural and ideological factors. The data used for such analysis is a modern British novel "Ann Veronica," which is written by H. G. Wells, a feminist writer, in 1909. The approach that is used for the analysis is Critical discourse analysis, which is used to investigate the way the characters in the novel perform gender, which also concentrates on revealing gender ideologies and gender power that cause gender inequality. The study also uses conversation analysis to show the organization of the conversation between the characters, male and female, which explain how the conversation is opened and closed and how the sequences are arranged between the characters. The most important conclusions are: gender stereotypes that cause gender inequality are performed in British society. Women are constructed as inferior to men. The study also concludes that women's gender identities are only limited to domestics. Besides, men have the most power in the society; that is why women are not allowed to be free and independent.
\end{abstract}

KEY WORDS: Analysis, Critical Discourse, Discourse, Gender Inequality, Gender

\section{INTRODUCTION}

Gender is someone's social identity, it should not be taken as a biological category of sex. Gender and sex are two different terms and they refer to different things. The critical discourse analysis (CDA) can reveal how gender is performed. Everyone performs gender, whether masculine or feminine, whereas the specific linguistic and non-linguistic devices tell how one performs masculine gender. The novel that has been selected for this paper to be analyzed shows how the male characters perform masculine gender using their

Koya University Journal of Humanities and Social Sciences (KUJHSS),

Volume 3, Issue 1, 2020.

Received 13 April 2020; Accepted 07 June 2020,

Regular research paper: Published 16 June 2020

Corresponding author's e-mail: lubna.fadhil@koyauniversity.org

Copyright (C2020 Lubna F. Ahmed \& Zhino J. Abubakr. This is an open access article distributed under the Creative Commons Attribution License. power to prevent women from living freely and having the economic independence, or do what they wish for.

\section{DISCOURSE AND DISCOURSE ANALYSIS}

The concept "discourse" dates back to the 14th century etymologically. It is taken from the Latin word "discursus," which means "conversation." However, the word "discourse" has been defined in different ways and by different scholars. (a) In traditional linguistics, it is defined as a unit of language that is larger than a sentence, (b) discourse is language in use, and (c) discourse is also defined as different types of language use or topics, for example, political media discourse...., etc. (Baker, 2006, p. 3). It can either be written or spoken (Trask, 1999, p. 52, Crystal, 2007, p. 260, Stubbs, 1983, pp. 1-5). Moreover, context is significant in using language when human speak or write, they do this according to the situation or the context in which they are involved. However, still, how humans talk or write create a specific situation or context (Gee, 1999, pp. 79-80). 
The approach to analyze discourse is called "discourse analysis," it started with Harris in 1952; he was the first one who called for the change of analysis; to go beyond the limit of the sentence to analyze a unit larger than a sentence which is called discourse. Harris (1952 cited in Widdowson, 2004, pp. 1-3) believes that "language does not occur in stray words or sentences, but in connected discourse;" however, Widdowson claims that Harris focused on the connectedness rather than on its discourse. However, today, DA is a vast field and means something more than just going beyond the limit of the sentence.

It can be noticed that DA has been defined according to two trends; the formal trend and the functional trend. The formal one defines it as the analysis of language beyond the limit of the sentence. The later defines it as the study of language in use (Drid, 2010, p. 21). However, Schiffrin (2006, cited in ibid: 21) connects the two approaches and defines DA as the study of language use above and beyond the limit of the sentence. Schmitt (2010, p. 54) adopts the functional approach in viewing DA, that is, he claims that discourse analysts do not deal with invented examples, but they deal with utterances (real conversations or texts) in a specific context; there must be a speaker, a hearer, a topic, and context. Without context, no analysis can be performed. Since DA is the study of language in use, and to study language, language use should not be studied in isolation, discourses also need to be considered and explored because discourses contain words, deeds, interactions, beliefs, feelings, things, means, times, and places that let us perform and recognize different socially situated identities (Gee, 2005, p. 35). Hence, in doing DA, social and cultural contexts should be considered this means that for Van Dijk, DA is a form of social practice (Van Dijk, 1997, p. 29).

In conclusion, one can say that discourse analysis is a vast field that is taken to mean so many things. It is the study of language beyond the limit of the sentence, which means that discourse analysts do not only focus on analyzing one sentence but a group of sentences that are combined to make texts. DA is also taken to mean the study of language use in social interactions. It is language behaviors that are connected to social practices, social circumstances, the physical conditions, and the context.

\section{CDA}

CDA was developed by a group of linguists and literary theorists, and it has been described as a multidisciplinary, complex domain of study (van Dijk,
1993, p. 1). CDA is more than just going beyond the limit of the sentence because it is more concerned with the broader message, philosophy, ideology, or idea conveyed. CDA tells the reader or the listener about the writer or the speaker's intention and reveals something hidden (Knapp and Daly, 2011, pp. 105-106). Furthermore, Gee and Handford (Gee and Handford, 2012, p. 616) explained that CDA is concerned with social problems rather than language structure. It is concerned with social life and the role of discourse in social life. For them, CDA is discourse study with an attitude. Aronoff and Rees-Miller stated that the goal of discourse analysis is not only to describe but also explain linguistic phenomena in terms of the effective, cognitive, situational, and cultural contexts of their use and to identify linguistic resources through which we (re)construct our identity, role, activity, community, emotion, stance, knowledge, belief, ideology, and so forth (Aronoff and Rees-Miller, 2001, pp. 446-467). In addition to this, CDA has a microlevel analysis, which includes language use, discourse, verbal interaction, and communication, and the macrolevel includes power, dominance, and inequality between social groups. It should be noticed that CDA focuses on the abuse of power, which causes social inequality and injustice such as gender, class, and race (van Dijk, 2008, p. 1).

In short, all people have values, ideas, ideologies, and intentions whether religious, economic, class, politics or academic...,etc., and all these values, intentions, and ideologies will be reflected in what is written or spoken and CDA is there to reveal these aspects. CDA reveals that a person is, what he or she believes, and what are his ideas, intentions, and conception of life..., etc.

\section{A. Van Dijk's Framework}

Van Dijk's is a prominent figure in CDA whose approach for CDA is a sociocognitive one. His model highlights the cognitive dimensions of how discourse operates in racism, ideology, and knowledge; he sees discourse as a social and cognitive framework. Indeed, Van Dijk's approach is called sociocognitive approach which explores the relationship between (1) mind, (2) discursive interaction, and (3) society; the model that he formulates is distinguished from other approaches in that it is the discourse-cognition-society triangle that is characterized with. Whereas in the other approaches of CDA, the focus is on the relationship between both discourse and society, in Van Dijk's model, the relationship between discourse and society is cognitively mediated; both discourse and social structures can be linked only to the mental representations of language user's individuals and as social members. In addition, 
social interaction, social situations, and social structures can only affect both text and talk through human interpretations of such social environments, which mean that there is no direct relationship between social structure and discourse structure (Van Dijk, 2015b, p. 64).

Van Dijk's model starts with the structural analysis, which means a systematic and explicit description of the text and talks structures at various levels like grammatical, morphological, or semantic levels. It also includes a level that is higher such as coherence, themes, and topics, ... etc. The model studies the cognitive features that connect discourse structure and society. Finally, his model analysis the social structure focusing on social inequality, domination, and ideologies. Van Dijk says that one can only relate discourse to society through the mind of participants, through the mind of language users. The third task is social analysis (Van Dijk, 2015b).

In short, Van Dijk's framework focuses more on the cognitive system and that is how it differs from Fairclough's framework because for Van Dijk (as mentioned above), the relationship between discourse and society is not direct, instead they are connected through cognition, which means that any written or spoken discourses are connected to the society through cognition.

\section{CONVERSATIONAL ANALYSIS}

Conversation is the most important uses of people's language because all people engage in conversational interactions, and human society relies on conversation to function because it is a way that helps the human beings to make friends, socialize, develop, and strengthen their relationship with others. Besides, conversations include not the linguistic codes, but it also includes something much more important such as the eye contact, body posture, silence, and the real-world context, in which the conversation is produced and that what makes the role of conversation meaningful in human interaction and social life (Liddicoat, 2011, p. 1). However, CA originated in the early 1960s at the University of California principled by the work of the sociologists (Sacks, Scheglof, and Jefferson) (Paltridge, 2006, pp. 106107). Moreover, it is concerned with naturally occurring interaction (Gee and Handford, 2012, pp. 120-121).

Moreover, according to Schegloff, 1997, cited in Mills, 2004 (Mills, 2004, p. 127), conversation analysis describes the organizational and structural peculiarities of interaction, drawing on the categories used by participants themselves. Moreover, interaction is affected by larger variables such as gender, class, race, or power relations if those who are involved in the interaction discuss these features clearly and make a distinction where these factors are considered to be necessary.

In general, the questions that conversational analysts want to answer are, how people in a conversation know their turn, what are the linguistic or sometimes nonlinguistic cues the addressee has which tells the addresser to be a listener or a speaker. Besides, CA does not deal only with informal and purely sociable talk, but it is also concerned with all sorts of interaction; informal to formal, from sociable to task focused, and from faceto-face interaction to synchronous technologically mediated interaction like telephone talk (Gee and Handford, 2012, pp. 120-121).

\section{THE CONCEPT OF GENDER}

Formally, the study of language and gender started in the 1970s, and due to the women's movements and the start of feminism language and gender problems became interrelated (Flotow, 2004 cited in Xia, 2013, p. 1).

The early work in gender and discourse analysis dealt with the relationship between language use and the biological category of sex, but this has changed and now moved to examine the ways that language is used in relation to the social category, or rather the socially constructed category, of gender. Hence, sex is a biological category, whereas gender is a social term that is used to indicate social identity that is constructed through social practices (Wardhaugh, 2011, pp. 333-334). Wodak (1997 cited in ibid) claims that gender is something someone does and it is not something that is possessed by someone and besides, it is not something one can avoid or run away from since it is a part of how societies are ordered around us. Again, Eckert and McConnel-Ginet (2003 cited in Ibid) stated that humans cannot live this life in a non-gendered way and it is not impossible to behave in a way that brings out gendered behavior in others, and this means that gender is the crucial component of identity as Wardhaugh claims. However, without any doubt, gender is someone's social identity, and no one can avoid it. Besides, gender is not like the biological term sex because gender is constructed through social actions, which means that it is something that is done by someone.

\section{ANALYSING ANN VERONICA NOVEL}

\section{A. Extract No. 1}

The participants in this dialogue are identified as Mr. Stanley (Ann's Father) and Miss Stanley (Mr. Stanley's 
sister). Mr. Stanley starts the conversation by asking her sister a question about a letter he wrote to his daughter, which contains his rejection of her daughter's going to London alone. Moreover, the letter that he wrote is firm and affectionate as it is described by her sister (Ann's aunt). Moreover, the conversation is opened by Mr. Stanley who called his sister to have her opinion about the letter he wrote "then he opened the study door and called 'Mollie'." However, the sequences of the conversation between them are well organized because Miss Stanley's response is relevant to Mr. Stanley's question and there is no interruption between them. Furthermore, the responses of Miss Stanley are preferable ones to those of Mr. Stanley because both of them agree on the matter.

Mr. Stanley: What do you think of that?

Miss Stanley: Yes, it is firm and affectionate. I could have said more.

You seem to have said just what had to be said. It seems to me exactly what is wanted. She really must not go to that affair

Miss Stanley paused and Mr. Stanley waited her to speak. Which means that Miss Stanely has not finished her turn and continued talking:

Miss Stanley: I don't think she quite sees the harm of those people or the sort of life to which they would draw her. "They just would spoil every chance."

Mr. Stanley: She has chances?

She is extremely attractive girl, to some people. Of course, one does not like to talk about things until there are things to talk about.

All the more reason why she should not get herself talked about.

This is exactly what I feel (p. 27-28).

After Ann decides to go to that dance project and after her father knew about that, her father wrote a letter to her to tell her that she is not allowed to go to London to that affair. Hence, in this extract, her father uses his power to limit the freedom of Ann's action. Furthermore, gender inequality is evident because he rejects her daughter's request using his authority as a father to prevent her from going there.

After this great turn of Miss Stanley, Mr. Stanley said nothing just thought of keeping her daughter save and make her happy. Besides, he sees her daughter as a little child that needs to take care of. That is why what Mr. Stanley thinks about is that he wants her daughter to be under her control as long as she is not married. He wants her daughter to get married and that how he thinks that Ann will be pleased without caring about what Ann wants or wishes for.

Moreover, Ann's father can also be seen as a very protective father not only due to his role as a father but also due to the society, the cruelty of the society plays a great role in his rejection to Ann's leaving:

"Mr. Stanley took the letter and stood with it in his hand thoughtfully for a time." "I'd give anything," he remarked, "to see our little Vee happily and comfortably married" (p. 27-28).

\section{B. Extract No. 2}

The participants in this extract are a father (Peter: Ann's father) and her daughter (Ann veronica). In this extract, it shows how her father keeps ignoring Ann and how he tries to keep himself away from discussing the matter. However, Ann keeps looking for a chance to talk to her father about the dance project in London, but her father keeps using his power and rejecting to talk about it and let her go to that affair:

"directly dinner was over Mr. Stanley, having pretended to linger to smoke, fled suddenly upstairs to petrography, and when Veronica tapped, he answered through locked door 'Go away, Vee! I'm busy,' and made a lapidary's wheel buzz loudly."

"Breakfast, too, was an impossible occasion, he reads the times with an unusually passionate intentness, and then declared suddenly for the earlier of the two trains he used" $(p, 29-30)$.

However, Ann Veronica insists on opening the topic with her father and never gives up. However, her father keeps not listening to her:

Ann: I'll come to the station, I may as well come up by this train

Her father: I may have to run, (said her father, with an appeal to his watch)

Ann: I will run too (she volunteered)

Instead of which they walked sharply....

Ann: I say daddy, (and was suddenly short of breath) $(p, 30)$

This conversation that happened so far shows the masculine gender of her father, which is evident in the extract above that explains the way her father tries to keep himself away from discussing the matter of the dance project. However, still, Ann keeps trying, and the evidence for that is that Ann followed her father to the station, although her father does not like that because he already knows why Ann tries to be with him and follows him. Moreover, when Ann wants to start talking, she becomes out of breath as it is described by the author "and was suddenly out of breath," and, that is, because her father runs fast so that he will not listen to what

Ann is going to say.

Her father: If it is about that dance project, it is no good Veronica. I've made up my mind. You will make me look a fool before all my friend 
You should not have made an engagement until you'd consulted your aunt.

Ann: I thought I was old enough (she gasped, between laughter and crying)

He father: I will not have you here quarreling and crying in the avenue. Stop it!. if you got anything to say, you must say it to your aunt

Ann: But look here, daddy!

He flapped the Times at here with an imperious gesture.

Her father: It is settled, you are not to go. You are NOT to go.

Ann: But its about other things.

Her father: I do not care. This is not a place.

Ann: Then may I come to the study to-night_after dinner?

Her father: I am _ BUSY!

Ann: It is important. If I cannot talk anywhere else__ I do want an understanding ( $\left.p, 31-32 \_\right)$.

It worth mentioning that gender is performed within constraints established by society's participants, which tells what appropriate things are and those which are not. Moreover, in case of Veronica and her father, their society has their own beliefs and traditions which do not allow women do what they wish for, just like Veronica whose father rejects that partly because he does not want to look like a fool in front of his friends.

for its something wrong and not appropriate: (You will make me look a fool before all my friend). However, their conversation contentious; her father keeps not listening to her and Ann keeps trying to make him agree. Although Ann believes that she is old enough to depend on herself, be free, and enjoy her life as she desires, her father, on the other hand, still rejects and uses his power to prevent her from going. Then, Ann interrupts her father by saying "but look her daddy!" At this point, her father performs his masculine gender when he starts to get angry showing her to stop talking about that and changes the tone of his voice and showing that he does not care about what she wishes and wants as it is evident in ("I don't care, this isn't a place" and "I am BUSY"). He wants Ann to be under his control.

Moreover, almost all the utterances that are made by Ann are followed by dispreferable answers or comments by her father like ("if it is about that dance project, it is no good Veronica. I've made up my mind." "I won't have you here, quarreling and crying in the avenue. Stop it!... if you got anything to say, you must say it to your aunt_." "it's settled, you are not to go. You're NOT to go." "I don't care. This isn't a place." "I'm _ BUSY!"). All these utterances show that they are dispreferable sequences to Ann's sequences. Besides, they all show gender inequality. The father keeps using his power by not listening to her, ignoring her, rejecting her ideas, raising his voice, and getting angry.

However, then, Ann succeeds in arranging an interview with her father talking about the dance project. Moreover, due to her enthusiastic, she interrupts her dad and sets a time for the discussion:

Her father: You have no right to badger me like this, Veronica. I cannot see what possible benefit can come of discussing things that are settled. If you want advice, your aunt is the person. However, If you must air your opinions

Ann: To-night, then daddy! (p, 32).

\section{Extract 3}

Ann: I want to be taken seriously. A girl - at my age - is grown up. I want to go on with my university work under proper conditions, now that I have done the intermediate. It is not as though I have not done well. I never muffed an exam yet. Roddy muffed two.......

Her father: Now look her Veronica, let us be plain with each other. You are not going to that infield Russell classes. You are not going anywhere but to the Tredgold college. I have thought that out. You must make up your mind. All sorts of considerations come in. While you live in my house you must follow my ideas $(p, 47)$.

This extract shows that Ann considers herself as a grown-up girl and can depend on herself; she explains how she succeeded till now compared to Roddy, her sister. After she made this comparison, her father interrupts her and does not let her say all that she wants because he thinks it's useless and will not affect him to change his mind, it also tells that her father is a firm person.

Ann: Then, I suppose when I have graduated, I am to come home?

Her father: It seems the natural course

Ann: And do nothing?

Her father: There are plenty of things a girl can do at home

Ann: Until someone takes pity on me and marries me? ( $p$, 47-48)

It tells that a man is in charge of social control, and women should ask their man or their father or the leader of the family before they do any activity. Ann feels hopeless due to her father's objection. She hates to live as what his father wishes. That also shows gender inequality and gender roles, male domination and female subordination, because according to the conversation occurred between them, she is not allowed to do what she wants, she has to live as his dad wants, and she has to accept this reality. Her father only wants 
her daughter to be under his care and control until she gets married.

After a lengthy discussion between them, Ann ended the conversation hopelessly and politely, and her father wants Ann to be happy about the discussion that her father made for her by showing her love:

Ann: Well, good night, father

Her father: What! Not a kiss? $(p, 51)$

\section{CONCLUSION}

As shown throughout this paper, gender is not the biological category, but it is the socially constructed category. The CDA that is done on the novel "Ann Veronica" shows that the characters perform gender because the male character performs his masculine gender by not letting her daughter Ann Veronica to get to the dance project that she wishes to go. Using his power as a father and as a masculine gender, he rejects her request no matter how her daughter feels. Moreover, society plays an important role in that because Ann lives in a society where men are superior and women are inferior.

\section{REFERENCES}

Aronoff, M. and Rees-Miller, J. (2001) The handbook of linguistics. Hoboken, New Jersey: Wiley Online Library, pp. 446-447.

Baker, P. (2006) Using corpora in discourse analysis. London: Aand C Black, p. 3.

Crystal, D. (2007) How language works. London: Penguin UK, p. 260.

Drid, T. (2010) Discourse Analysis: Key concepts and perspectives. Ouargla, Argelia: Kasdi Merbah University, p. 21.

Gee, J.P. (2005) An introduction to discourse analysis: Theory and method. London, New York: Routledge, p. 35.

Gee, J.P. and Handford, M. (2012) The Routledge handbook of discourse analysis. London, New York: Routledge, pp. 616, 120121.

Gee, J.P. (1999) An introduction to discourse analysis: Theory and method. London, New York: Routledge, pp. 79-80.

Knapp, M.L. and Daly, J.A. (2011) The sage handbook of interpersonal communication. Thousand Oaks: SAGE.

Liddicoat, A.J. (2011) An introduction to conversation analysis. London: Bloomsbury Publishing, p. 1.

Mills, S. (2004) Discourse. London, New York: Routledge, p. 127.

Paltridge, B. (2006). Discourse analysis: An introduction. London, New York: Continuum, pp. 106-107.

Schmitt, N. (2010) An introduction to applied linguistics. London: Hodder Education, p. 52.

Stubbs, M. (1983) Discourse analysis. Oxford: Blackwell, pp. 1-5.

Trask, R.L. (1999) Key concepts in language and linguistic. London, New York: Routledge, p. 52.
Van Dijk, T.A. (1993) Principles of critical discourse analysis. Discourse and Society, 4, p. 1.

Van Dijk, T.A. (2008) Discourse and power. Basingstoke: Macmillan International Higher Education, p. 1.

Van Dijk, T.A. (2015b) Critical discourse studies: A sociocognitive approach. In: Methods of Critical Discourse Studies. London: SAGE, pp. 63-74.

Van Dijk, T.A. (1997) The study of discourse. Discourse as structure and process. Amsterdam: Benjamins, p. 29.

Wardhaugh, R. (2011) An introduction to sociolinguistics. New York: John Wiley and Sons, pp. 333-334.

Wells, H.G. (1909) Ann Veronica, a modern love story. New York and London: Harper and brothers, pp. 27-28, 31-32.

Widdowson, H.G. (2004) Text, context, pretext: Critical issues in discourse analysis. Vol. 1-4. Malden, USA/Oxford: Blackwell Publishing, p. 15.

Xia, X. (2013) Gender differences in using language. Theory and Practice in Language Studies, 3(8), pp. 1485-1489. 